\title{
Molecular Detection of Hepatitis C Virus (HCV) by Conventional One-step RT-PCR Coupled with Nested PCR
}

\author{
Vikrant Sharma ${ }^{1}$, Deepak Kumar ${ }^{2}$, Divya Dhull ${ }^{1}$, Sulochana Kaushik ${ }^{3}$, \\ Jaya Parkash Yadav ${ }^{3}$ and Samander Kaushik ${ }^{1^{*}}$ \\ ${ }^{1}$ Centre for Biotechnology, Maharshi Dayanand University, Rohtak, India. \\ ${ }^{2}$ Department of Biotechnology and Molecular Medicine, Pt BDS, PGIMS, Rohtak, India. \\ ${ }^{3}$ Department of Genetics, Maharshi Dayanand University, Rohtak, India.
}

\section{Authors' contributions}

This work was carried out in collaboration between all authors. Author VS did the laboratory work, data analyses and contributed in writing manuscript. Authors DK, DD and JPY contributed in writing manuscript. Author Sulochana Kaushik managed the analyses of the study and literature searches. Author Samander Kaushik designed the study and contributed in writing protocol and manuscript. All authors read and approved the final manuscript.

Article Information

DOI: $10.9734 /$ IBRR/2017/34463

Editor(s):

(1) Ricardo Forastiero, Department of Hematology, Favaloro University, Argentina. Reviewers:

(1) Y. J. Peter, University of Abuja, Nigeria. (2) Lívia Garcia Bertolacci-Rocha, Universidade Federal de Goiás, Brasil. (3) Shamala Moodley, Mangosuthu University of Technology, South Africa. Complete Peer review History: http://www.sciencedomain.org/review-history/19547

Short Research Article

Received $29^{\text {th }}$ May 2017

Accepted $14^{\text {th }}$ June 2017

Published $15^{\text {th }}$ June 2017

\section{ABSTRACT}

Aims: HCV causes both acute and chronic infections and can be easily transmitted through contaminated blood or other body fluids. The present study deals with the molecular detection of HCV with help of one-step RT-PCR assay followed by nested PCR and agarose gel electrophoresis. Study Design: RNA extracted from the confirmed positive samples of HCV was utilized for the standardization of the one-step RT-PCR assay and nested PCR assay for diagnosis of HCV.

Place and Duration of Study: Centre for Biotechnology, Maharshi Dayanand University, Rohtak Haryana, India, during period of one year (January-December 2015).

Methodology: HCV positive samples were obtained from Department of Medicine, Maulana Azad Medical College (MAMC), New Delhi, India. Published primers from most conserved regions of HCV were taken and these primers were able to amplify all the strains of HCV. One-step RT-PCR kits, 
primers, extracted RNA from these positive samples were used for standardization of molecular diagnostic assays. The results were checked by $2 \%$ agarose gel electrophoresis.

Results: Positive samples of HCV were detected by nested PCR. Positive samples showed sharp band of $405 \mathrm{bp}$ while there was no amplification in the negative control.

Conclusion: Rapid tests have low sensitivity and specificity while molecular assays are rapid, sensitive and specific. Conventional one-step RT-PCR assay followed by nested PCR is rapid, specific, sensitive and it is also less costly than real-time RT-PCR. Cost of an assay is an important factor in controlling a disease in resource limited settings of developing countries.

Keywords: Hepatocellular carcinoma; conventional PCR; viral hepatitis; hepatitis C virus, one-step RT-PCR, nested PCR, molecular diagnosis.

\section{ABBREVIATIONS}

$\begin{aligned} \text { ELISA } & \text { Enzyme Linked Immunosorbent } \\ & \text { Assay } \\ \text { HCV } & : \text { Hepatitis C Virus } \\ \text { RT-PCR } & \text { Reverse Transcriptase Polymerase } \\ & \text { Chain Reaction } \\ \text { WHO } & : \text { World Health Organization }\end{aligned}$

\section{INTRODUCTION}

Hepatitis $C$ Virus (HCV) is one of the important viruses among other hepatitis viruses $(A, B, D$, and $E)$ which are responsible for serious chronic infection of liver. First case of HCV was reported in the serum of a patient with Non-A, Non-B hepatitis by Choo et al. in 1989 [1]. HCV is a small $(50 \mathrm{~nm})$, enveloped, single-stranded, positive-sense RNA virus of family Flaviviridae and genus Hepacivirus. Genome of HCV contains 9500 nucleotides with one open reading frame which encodes for about 3000 amino acid polypeptides [2]. HCV contains highly variable genome with more than six major genotypes of HCV which are circulating worldwide [3]. An estimate made by World Health Organization (WHO) showed that about 71 million people have chronic hepatitis and about 0.4 million people die each year due to cirrhosis and hepatocellular carcinoma [4]. Another study estimated the number of HCV infected people may be 150-200 million globally $[4,5,6]$. The distribution pattern of $\mathrm{HCV}$ is not equal, with higher occurrence in developing part than the developed part of the world due to less health infrastructure and poor blood screening facilities. In India, there is no specific viral surveillance system, resulting in lack of exact data about $\mathrm{HCV}$ infections. Although some recent study estimated that prevalence of $\mathrm{HCV}$ is about $1.5 \%$ in India [5]. $\mathrm{HCV}$ is mainly spread by direct contact with infected blood or body fluids. HCV can be transmitted through the blood transfusion and items like contaminated needles, syringes or other medical equipment and needle-sharing among intravenous drug abusers [7]. Other social, cultural and behavioral practices (e.g., piercing, circumcision, tattooing) may become the reason for spreading of $\mathrm{HCV}$, if inadequately sterilized equipments are used. Sexual transmission may also occur between partners although less frequently. Like HIV, HCV does not spread by sneezing, hugging, coughing, food or water, sharing eating utensils and casual contact $[2,7,8,9]$. HCV infections are broadly divided into acute and chronic types. Acute HCV occurs after an incubation period of 15 - 60 days with majority of acute HCV infections doesn't show any symptoms [10]. Chronic HCV infections are less prevalent but more risky than acute infections and can cause liver cirrhosis and cancer in some cases. The clinical symptoms may vary from mild to life threatening. HCV patients show symptoms like malaise, vomiting, fatigue, lethargy, anorexia, abdominal pain, myalgia, jaundice, mild hepatosplenomegaly, maculopapular rash and arthralgia $[2,5,7]$.

Clinically, we cannot differentiate $\mathrm{HCV}$ from other hepatitis viruses and precise diagnosis is possible with laboratory methods only. Laboratory diagnosis of $\mathrm{HCV}$ is done by conventional biochemical markers and liver function test (LFT) [2]. The most practical screening test for HCV infection is the enzyme linked immunosorbent assay (ELISA) but it has low sensitivity and specificity. Moreover, false positive ELISA results may occur in patients with autoimmune antibodies, paraproteinemia, EBVinfection or other reasons $[2,7,11,12]$. Recently, few companies have introduced some rapid detection kits for HCV but these also struggle with poor sensitive and specificity issues. The reverse transcription polymerase chain reaction (RT-PCR) is the most used direct method to detect HCV RNA in blood [13,14]. Molecular assays are preferred for the confirmation of HCV infections because of their high sensitivity. But 
$\mathrm{HCV}$ is a very slow replicating virus, containing low copy number and some RNA may be degraded during isolation process making conventional RT-PCR less sensitive. Conventional RT-PCR coupled with nested PCR has been used successfully for effective detection of HCV infections [15,16,17]. Real-time RT-PCR is another choice with high sensitivity and specificity but sophisticated equipments and costly reagents make the assay less economic for use in developing countries. As HCV is a highly dangerous virus having the capability to infect large segment of world population, the present study has been conceptualized to develop one-step RT-PCR assay followed by nested PCR for sensitive, specific and cost effective detection of HCV.

\section{MATERIALS AND METHODS}

\subsection{Positive Samples of Hepatitis C Virus (HCV)}

HCV positive samples were obtained from the Department of Medicine, Maulana Azad Medical College (MAMC), New Delhi. At MAMC, these samples were positive for $\mathrm{HCV}$ by conventional RT-PCR and further confirmed by sequencing.

\subsection{RNA Extraction from Positive Samples}

Viral RNA was extracted from $200 \mu \mathrm{l}$ of an aliquot of HCV positive sample. RNA extraction was done with the help of GeneJET Viral DNA/RNA Purification Kit (Thermo Fisher Scientific, USA) according to the manufacturer's protocol. RNA was eluted with $50 \mu \mathrm{l}$ of elution buffer and stored at $-70^{\circ} \mathrm{C}$ for further use.

\subsection{Standardization of One-step RT-PCR and Nested PCR for HCV Using Reference Strains}

First round of one-step RT-PCR was standardized using Verso 1-Step RT-PCR Kit
(Thermo Fisher Scientific, USA) as per manufacturer's instructions. Twenty five microliters of reaction mixture was prepared by adding $5 \mu \mathrm{l}$ of extracted viral RNA and $0.2 \mu \mathrm{M}$ of both outer forward and outer reverse primers into the master mixture. $5 \mu \mathrm{l}$ of double distilled water was added into negative control. In One-Step RT-PCR assay, initially RT (conversion of RNA into cDNA) step was performed after that heat inactivation of RT enzyme was done followed by simple PCR steps. Second round of nested PCR was performed using $5 \mu \mathrm{l}$ of amplicons of onestep RT-PCR as template. The reaction mixture comprised of $2.5 \mu \mathrm{l}$ of $10 \times$ Taq buffer (Bangalore Genei) with $15 \mathrm{mM} \mathrm{MgCl}_{2}, 0.2 \mathrm{mM}$ of each dNTPs (Bangalore Genei), $0.2 \mu \mathrm{M}$ of both internal forward and internal reverse primers and $0.75 \mathrm{U}$ Taq DNA polymerase (Bangalore Genei). Negative controls were also included in the assay.

\subsection{Primers for One-step RT-PCR and Nested PCR}

Published primers were selected from the 5' UTR- core region of HCV which is conserved region for all serotypes and able to amplify all strains of HCV [18]. The specificity of these primers was also checked by BLAST (Bioinformatics tool/software) at $\mathrm{NCBI}$ site. Details of primers are given in Table 1.

\subsection{Agarose Gel Electrophoresis}

Nested PCR amplified products were visualized on $2.5 \%$ agarose gel. Agarose gel was prepared in $1 \mathrm{X}$ TAE (Tris acetate EDTA buffer, $\mathrm{pH}$ 8) buffer and the amplicons were loaded with the help of $2 \mu \mathrm{l}$ of $1 \mathrm{X}$ gel loading dye (Bangalore Genei). Electrophoresis was performed for about 60 min at a constant voltage of $80 \mathrm{~V}$ in running buffer containing $1 \mathrm{X}$ TAE and ethidium bromide $(1 \mu \mathrm{g} / \mathrm{ml})$. After electrophoresis gel was visualized in a gel documentation system or gel transilluminator.

Table 1. External and internal primers used in one-step RT-PCR and nested PCR

\begin{tabular}{llllll}
\hline $\begin{array}{l}\text { S. } \\
\text { no. }\end{array}$ & Primer name & Sequences (5'-3') & $\begin{array}{l}\text { Amplicon } \\
\text { size (bp) }\end{array}$ & $\begin{array}{l}\text { Primer } \\
\text { length }\end{array}$ & Reference \\
\hline 1 & Outer Forward & ACTGCCTGATAGGGTGCTTGCGAG & & 25 & \\
2 & Outer Reverse & CCATGTACCATGAKRTCGGC & 631 & 21 & {$[17]$} \\
3 & Inner Forward & AGGTCTCGTAGACCGTGCATCATG & & 25 & \\
4 & Inner Reverse & CAYGTRAGGGTATCGATGAC & 405 & 21 & \\
\hline
\end{tabular}




\section{RESULTS}

\subsection{Optimization of One-step RT-PCR and Nested PCR}

One-step RT-PCR assay was standardized with $0.2 \mu \mathrm{M}$ of external forward \& reverse primers. Optimum RNA template amount was found to be $5 \mu \mathrm{l}$ and 35 cycles were optimized for the onestep RT-PCR assay. Optimal cyclic conditions for one-step RT-PCR assay are given in Table 2 .

Similarly nested PCR was also standardized by using $0.2 \mu \mathrm{M}$ of internal forward \& reverse primers and $5 \mu \mathrm{l}$ of one-step RT-PCR product (first round). Negative controls were also included which contain $5 \mu \mathrm{l}$ of nuclease free water in place of template DNA. Optimal cycling conditions for nested-PCR assay are given in Table 3.

After nested PCR assay the amplified products were electrophoresed using $2.5 \%$ agarose gel and positive sample showed a sharp band of 405 bp while there was no band in the negative controls (Fig. 1).

\subsection{Specificity of the Assay}

One-step RT-PCR and nested PCR assay were highly specific for HCV detection as these assays failed to detect RNA/DNA of other related hepatitis viruses $(A, B, D$ and $E)$.

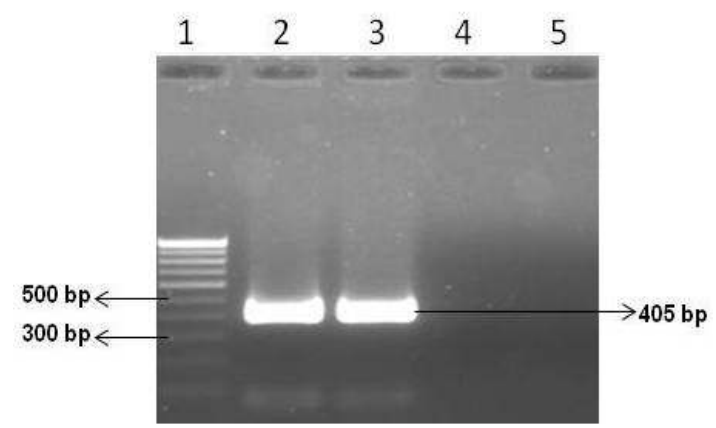

Fig. 1. Standardization of one step RT- PCR and nested PCR assay on HCV positive samples

Lane 1,100 bp DNA marker; lane 2 and 3, HCV positive samples; lane 4 and 5 , negative controls

\section{DISCUSSION}

Hepatitis C viruses are responsible for both acute and chronic infections of liver thereby affecting the large segment of global population. Studies have shown that around 150-200 million people are infected with acute or chronic liver ailments worldwide [4,5,6]. Currently, there is no vaccine available for HCV but timely treatment with antiviral medicines can cure the disease. Thus a rapid, sensitive, specific and cost effective diagnosis of $\mathrm{HCV}$ plays a crucial role in the prophylaxis of the disease.

Table 2. Thermal cycling conditions for one-step RT-PCR assay

\begin{tabular}{llll}
\hline S. no. & Steps & Temperature $\left({ }^{\circ} \mathbf{C}\right)$ & Time \\
\hline 1 & Reverse transcription & 50 & $60 \mathrm{Min}$ \\
2 & Heat inactivation & 95 & $15 \mathrm{Min}$ \\
3 & Initial denaturation & 95 & $03 \mathrm{Min}$ \\
4 & Denaturation & 95 & $45 \mathrm{Sec}$ \\
5 & Annealing & 50 & $45 \mathrm{Sec}$ \\
6 & Extension & 72 & $45 \mathrm{Sec}$ \\
7 & Final extension & 72 & $07 \mathrm{Min}$ \\
8 & Storage & 4 & $\infty$ \\
9 & Number of cycle & 35 Cycle (step 4-6) & \\
\hline
\end{tabular}

Table 3. Optimal cycling conditions for nested-PCR assay

\begin{tabular}{llll}
\hline S. no. & Steps & Temperature $\left({ }^{\circ} \mathbf{C}\right)$ & Time \\
\hline 1 & Initial denaturation & 95 & $03 \mathrm{Min}$ \\
2 & Denaturation & 95 & $45 \mathrm{Sec}$ \\
3 & Annealing & 50 & $45 \mathrm{Sec}$ \\
4 & Extension & 72 & $45 \mathrm{Sec}$ \\
5 & Final extension & 72 & $07 \mathrm{Min}$ \\
6 & Storage & 4 & $\infty$ \\
7 & Number of cycle & 35 Cycle (step 2-4) & \\
\hline
\end{tabular}


Presently $\mathrm{HCV}$ is diagnosed by rapid commercial kits, ELISA, biochemical marker, RT-PCR and real-time RT-PCR. ELISA and rapid commercial kits have low sensitivity and specificity for different hepatitis virus strains and can generate false positive results $[2,7,11,12]$. PCR based assays are the most direct approach to detect HCV RNA in blood [13-15]. Confirmed virus detection and typing could be possible by virus isolation but absence of virus isolation in cell culture hampers the research on HCV. Molecular detection methods are replacing traditional virus culture methods as these are more rapid, sensitive and specific [18-22]. Molecular diagnostic assays are more reliable than virus isolation and rapid kits. Conventional RT-PCR, real-time RT-PCR, transcription mediated amplification and branched DNA based assays are the most common molecular methods used for the detection and quantification of $\mathrm{HCV}$ $[23,24]$.

In the present study HCV diagnosis was done by one-step RT-PCR assay followed by nested PCR. This method was based on two rounds of PCR amplification thereby increasing the detection time but the sensitivity and specificity of the assay was high. As HCV is a very slow growing virus and producing small number of virion particles per cell, hence we need nested types of PCR to produce the enough DNA to be detected. Amplified products can be seen in the agarose gel after staining with ethidium bromide. According to literature, nested RT-PCR assay demonstrated comparable sensitivity and specificity when compared to other methods like real-time RT-PCR. Real time RT-PCR approach although considered as more rapid, sensitive and specific but too expensive for large-scale diagnosis and has not been widely used in the majority of clinical laboratories in developing countries [13-15,21-23]. The primer sequences used as external and internal primers in the assay were highly conserved and specific for HCV only making the assay non-specific for other related viruses like hepatitis $A, B, D$ and $E$. This assay can be used as diagnostic tool for clinicians and also can be used for epidemiological surveillance studies and screening blood donors and would be suitable for any resource limited setup.

\section{CONCLUSION}

In the present study, a specific, sensitive and cost effective diagnostic assay for HCV was developed. Presently, HCV is detected by simple biochemical assays, rapid tests and modern molecular assays. Rapid tests have low sensitivity and specificity while molecular assays like real-time PCR are more rapid, sensitive and specific but costly. Cost of a diagnostic assay is an important factor in the developing countries like India. Non-availability of effective vaccines and antivirals make HCV infections more dangerous and a major problem world-wide. The present diagnostic assay was standardized using confirmed positive reference samples of $\mathrm{HCV}$ virus. The RT-PCR coupled nested PCR assay can be applied directly on HCV suspected patients' samples providing sensitive, specific, rapid and cost effective result within the reasonable time and cost. There is still a need to develop some therapeutic agents and vaccines against HCV infections. The present assay can be modified in multiplex format according to the need of time.

\section{CONSENT}

It is not applicable.

\section{ETHICAL APPROVAL}

It is not applicable.

\section{COMPETING INTERESTS}

Authors have declared that no competing interests exist.

\section{REFERENCES}

1. Choo QL, Kuo G, Weiner AJ, Overby LR, Bradley DW, Houghton M. Isolation of a cDNA clone derived from a blood-borne non-A, non-B viral hepatitis genome. Science. 1989;244(4902):359-62.

2. Fauci AS, Braunwald E, Isselbacher KJ, Wilson JD, Martin JB, Kasper DL, et al. Harrison's principles of internal medicine. 14th ed. Singapore: McGraw-Hill; 1998.

3. Simmonds $\mathrm{P}$, Bukh J, Combet $\mathrm{C}$, Deléage $\mathrm{G}$, Enomoto $\mathrm{N}$, Feinstone $\mathrm{S}$, et al. Consensus proposals for a unified system of nomenclature of hepatitis $C$ virus genotypes. Hepatology. 2005;42(4):96273.

4. World Health Organization. Hepatitis C. Fact sheet.

Available:http://www.who.int/mediacentre/f actsheets/fs164/en/

(Accessed April 2017) 
5. Lavanchy D. Evolving epidemiology of hepatitis C virus. Clin Microbiol Infect. 2011;17(2):107-15.

6. Mohd Hanafiah K, Groeger J, Flaxman AD, Wiersma ST. Global epidemiology of hepatitis $\mathrm{C}$ virus infection: New estimates of age-specific antibody to HCV seroprevalence. Hepatology. 2013;57(4): 1333-42.

7. Wong T, Lee SS. Hepatitis C: A review for primary care physicians. C Med Assoc J. 2006;17:649-59.

8. Tsukiyama-Kohara K, lizuka N, Kohara M, Nomoto A. Internal ribosome entry site within hepatitis $\mathrm{C}$ virus RNA. J Virol. 1992;66(3):1476-83.

9. Wang CS, Wang ST, Yao WJ, Chang TT, Chon P. Community-based study of hepatitis $C$ virus infection and type 2 diabetes: An association affected by age and hepatitis severity status. Am J Epidemol. 2003;158(12):1154-60.

10. Pawlotsky JM. Use and interpretation of virological tests for hepatitis C. Hepatology. 2002;36:S65-73.

11. Lok ASF, Gunaratnam NT. Diagnosis of hepatitis C. Hepatology. 1997;26:48S-56S.

12. Halfon $P$, Bourliere M, Penaranda G, Khiri $H$, Ouzan D. Real-time PCR assays for hepatitis $\mathrm{C}$ virus (HCV) RNA quantitation are adequate for clinical management of patients with chronic HCV infection. J Clin Microbiol. 2006;44(7):2507-11.

13. Cook L, Sullivan K, Krantz EM, Bagabag A, Jerome KR. Multiplex real-time reverse transcription-PCR assay for determination of HCV genotypes. J Clin Microbiol. 2006;44(11):4149-56.

14. Young KK, Archer JJ, Yokosuka O, Omata M, Resnick RM. Detection of hepatitis C virus RNA by a combined reverse transcription PCR assay: Comparison with nested amplification and antibody testing. J Clin Microbiol. 1995;33(3):654-57.

15. Aslanzadeh J, Padilla BB, Shanley JD. Evaluation of PCR and nested PCR for laboratory diagnosis of hepatitis $\mathrm{C}$ virus infection. Mol Cell Probes. 1996;10(3):17378 .
16. Krekulova L, Rehak V, Wakil AE, Harris E, Riley LW. Nested restriction site-specific PCR to detect and type hepatitis $C$ virus (HCV): A rapid method to distinguish $\mathrm{HCV}$ subtype $1 \mathrm{~b}$ from other genotypes. J Clin Microbiol. 2001;39(5):1774-80.

17. Kumar D, Malik A, Asim M, Chakravarti A, Das $\mathrm{RH}$, Kar P. Influence of quasispecies on virological responses and disease severity in patients with chronic hepatitis C. World J Gastroenterol. 2008;14(5):70108.

18. Sharma V, Kaushik S. Comparative analysis of molecular methods for detection of influenza viruses. British Microbiol Res J. 2016;17(3):1-10.

19. Broor S, Chahar HS, Kaushik S. Diagnosis of influenza viruses with special reference to novel H1N1 2009 influenza virus. Indian J Microbiol. 2009;49(4):301-07.

20. Dhakad S, Mali PC, Kaushik S, Lal AA, Broor S. Comparison of multiplex RT-PCR with virus isolation for detection, typing and sub-typing of influenza virus from influenza-like illness cases. Indian J Med Microbiol. 2015;33(1):73-77.

21. Sharma V, Kumar D, Dhull D, Kaushik S, Kaushik S. Molecular detection of hepatitis $B$ viruses (HBV). Int Blood Res Rev. 2017;7(1):1-6.

22. Patel K, Muir AJ, McHutchison JG. Diagnosis and treatment of chronic hepatitis C infection. BMJ. 2006; 332(7548):1013-17.

23. Cantaloube JF, Laperche S, Gallian P, Bouchardeau $F$, de Lamballerie $X$, de Micco P. Analysis of the 5' noncoding region versus the NS5b region in genotyping hepatitis $\mathrm{C}$ virus isolates from blood donors in France. J Clin Microbiol. 2006;44(6):2051-56.

24. Ito T, Yasui K, Mukaigawa J, Katsume A, Kohara M, Mitamura K. Acquisition of susceptibility to hepatitis $\mathrm{C}$ virus replication in HepG2 cells by fusion with primary human hepatocytes: Establishment of a quantitative assay for hepatitis $\mathrm{C}$ virus infectivity in a cell culture system. Hepatology. $2001 ; 34(3): 566-72$.

(c) 2017 Sharma et al.; This is an Open Access article distributed under the terms of the Creative Commons Attribution License (http://creativecommons.org/licenses/by/4.0), which permits unrestricted use, distribution, and reproduction in any medium, provided the original work is properly cited.

Peer-review history:

The peer review history for this paper can be accessed here: http://sciencedomain.org/review-history/19547 